Check for updates

Cite this: RSC Adv., 2019, 9, 7485

Received 23rd January 2019

Accepted 20th February 2019

DOI: 10.1039/c9ra00596j

rsc.li/rsc-advances

\section{Preparation, characterization and application in cobalt ion adsorption using nanoparticle films of hybrid copper-nickel hexacyanoferrate $\dagger$}

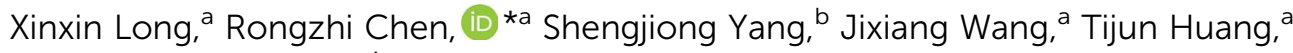 \\ Qin Lei ${ }^{\mathrm{a}}$ and Jihua Tan*a
}

\begin{abstract}
Different mole ratios $\left(n_{\mathrm{Cu}}: n_{\mathrm{Ni}}=x: y\right.$ ) of hybrid copper-nickel metal hexacyanoferrates (Cux $\mathrm{Ni}_{y} \mathrm{HCFs}$ ) were prepared to explore their morphologies, structure, electrochemical properties and the feasibility of electrochemical adsorption of cobalt ions. Cyclic voltammetry (CV), field emission scanning electron microscopy (FE-SEM), Fourier transform infrared spectroscopy (FTIR) and X-ray diffraction (XRD) indicated that the $x$ : $y$ ratio of $\mathrm{Cu}_{x} \mathrm{Ni}_{y} \mathrm{HCF}$ nanoparticles can be easily controlled as designed using a wet chemical coprecipitation method. The crystallite size and formal potential of $\mathrm{Cu}_{x} \mathrm{Ni}_{y} \mathrm{HCF}$ films showed an insignificant change when $0 \leq x: y<0.3$. Given the shape of the $\mathrm{CV}$ curves, this might be due to $\mathrm{Cu}^{2+}$ ions being inserted into the NiHCF framework as countercations to maintain the electrical neutrality of the structure. On the other hand, crystallite size depended linearly on the $x: y$ ratio when $x: y>0.3$. This is because $\mathrm{Cu}$ tended to replace $\mathrm{Ni}$ sites in the lattice structure at higher molar ratios of $x: y . \mathrm{Cu}_{x} \mathrm{Ni}_{y} \mathrm{HCF}$ films inherited good electrochemical reversibility from the CuHCFs, in view of the cyclic voltammograms; in particular, $\mathrm{Cu}_{1} \mathrm{Ni}_{2} \mathrm{HCF}$ exhibited long-term cycling stability and high surface coverage. The adsorption of $\mathrm{Co}^{2+}$ fitted the Langmuir isotherm model well, and the kinetic data can be well described by a pseudo-second order model, which may imply that $\mathrm{Co}^{2+}$ adsorption is controlled by chemical adsorption. The diffusion process was dominated by both intraparticle diffusion and surface diffusion.
\end{abstract}

\section{Introduction}

Iron hexacyanoferrate (PB, Prussian blue) and its analogues (PBAs) are collectively referred to as transition metal hexacyanoferrates (MHCFs, $\mathrm{M}=\mathrm{Fe}, \mathrm{Cu}, \mathrm{Co}, \mathrm{Ni}$, etc.) Due to the electrochromism, magnetism, redox activity, and electrochemical stability associated with their unique cubic structure, MHCFs have been applied in a number of fields, including catalysis, ${ }^{1}$ electrochromics, ${ }^{2}$ electrocatalysis, ${ }^{3,4}$ detection, ${ }^{5}$ chemical sensors, ${ }^{6}$ capacitors, ${ }^{7}$ secondary batteries, ${ }^{8}$ photocatalysis, ${ }^{9}$ photochromics, ${ }^{10}$ biosensors, ${ }^{11,12}$ and metal ion sieving or capture, ${ }^{\mathbf{1 3}, \mathbf{1 4}}$ making great contributions to environmental technology and new-generation energy development.

Recently, MHCFs have received extensive attention due to their unique electrochemical properties as modified electrode materials, such as $\mathrm{PB}(\mathrm{FeHCF}),{ }^{\mathbf{1 5}}$ copper hexacyanoferrate

${ }^{a}$ College of Resources and Environment, University of Chinese Academy of Sciences, Yuquan Road 19A, Beijing 100049, China. E-mail: crz0718@ucas.ac.cn; tanjh@ ucas.ac.cn

${ }^{b}$ Key Laboratory of Environmental Engineering, Xi'an University of Architecture and Technology, No. 13, Yanta Road, Xi'an, Shaanxi 710055, China

$\dagger$ Electronic supplementary information (ESI) available. See DOI: 10.1039/c9ra00596j
(CuHCF), ${ }^{16}$ cobalt hexacyanoferrate (CoHCF), ${ }^{17}$ nickel hexacyanoferrate (NiHCF), ${ }^{18}$ and zinc hexacyanoferrate (ZnHCF). ${ }^{19}$ Each MHCF has its own unique electrochemical and spectral properties; however, materials with diversified traits are preferred. Research into hybrid-metal hexacyanoferrates (hMHCFs) is becoming a trend due to their multiple characteristics and properties. Previous researchers reported that the prepared h-MHCFs existed as a new phase rather than a simple mixture of corresponding single metal hexacyanoferrates. ${ }^{20,21}$ Ghasemi et al. ${ }^{22}$ found that NiCoHCF has a higher capacitance than NiHCF or CoHCF; Li et al. ${ }^{23}$ revealed that CuNiHCF has a higher capacity retention than CuHCF as a cathode for sodium-ion batteries; it was also reported that the mixed MHCF showed an enhanced catalytic efficiency to $\mathrm{H}_{2} \mathrm{O}_{2}$ as compared to that of FeHCF. ${ }^{24}$ The surface coverage of CoNiHCF was proved to be higher than those of CoHCF and NiHCF. ${ }^{25}$

In an aqueous electrolyte containing alkali salts, MHCFs exhibit reversible redox reactions (such as $\mathrm{Fe}^{\mathrm{III}} / \mathrm{Fe}^{\mathrm{II}}$ ) accompanied by reversible intercalation and deintercalation of hydrated alkali cations, low cost, and low toxicity. ${ }^{26}$ Within the family of MHCFs, an NiHCF modified electrode showed an excellent cation exchange capacity in redox reactions due to its open structural framework, ${ }^{27-29}$ with uniform, compact and stable films. The network structures with macropores ${ }^{26}$ of CuHCF 
films were characterized by nearly ideal current-potential curves. ${ }^{30}$ We also found that a CuNiHCF film modified electrode showed higher electrochemical stability in comparison to CuHCF and NiHCF in phosphate buffer solutions (PBS). ${ }^{25}$ To the best of our knowledge, few papers on different proportions of $\mathrm{Cu}_{x} \mathrm{Ni}_{y} \mathrm{HCF}$ nanoparticle films as modified electrode materials have been published, which inspired us to synthesize $\mathrm{Cu}_{x} \mathrm{Ni}_{y^{-}}$ HCF films that may inherit the virtues of CuHCF and NiHCF.

Generally, MHCF film modified electrodes are prepared by electrodeposition, and are difficult to produce on a large scale, ${ }^{25}$ and fall off easily. Moreover, it is hard to control the proportion of metal phases $\left(\mathrm{M}_{1}: \mathrm{M}_{2}\right)$ in the products (h-MHCFs), which is why few researchers have focused on the characteristic differences among varied proportions of h-MHCFs, such as morphology, structure, or electrochemical properties. Chen et $a l .{ }^{31}$ prepared exact ratios of CuHCF nanoparticle ink by a wet chemical coprecipitation method, and printed them onto the electrode surface to remove cesium electrochemically; the cesium removal was comparable in magnitude to that by an electrodeposited film. Wang et al. ${ }^{25}$ prepared h-MHCF films by the same method; the surface coverage of redox-active sites of

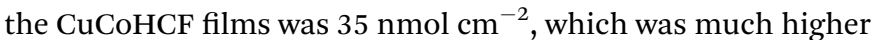
than the $9.02 \mathrm{nmol} \mathrm{cm}^{-2}$ of electrodeposited films; ${ }^{32}$ and the $\mathrm{Co} / \mathrm{Ni}$ atomic ratio in CoNiHCF compounds had been proved to be controlled by the reactant ratio in the reaction mixture.

Herein, we prepared a series of $\mathrm{Cu}_{x} \mathrm{Ni}_{y} \mathrm{HCF}$ nanoparticle films with different molar ratios $\left(n_{\mathrm{Cu}}: n_{\mathrm{Ni}}=x: y\right)$ by using a wet chemical coprecipitation method, and explored the characteristics of each ratio and the variations among them by multiple characterization methods. Recently, the wide application of lithium-ion batteries (LIBs) has resulted in a rapid increase in the amount of spent LIBs, containing valuable metals such as cobalt, lithium, nickel, and copper. Therefore, we also attempt to recover cobalt ions $\left(\mathrm{Co}^{2+}\right)$ from solutions by using $\mathrm{Cu}_{x} \mathrm{Ni}_{y} \mathrm{HCF}$ nanoparticle films. The feasibility of electrochemical adsorption of cobalt ions onto hybrid copper-nickel hexacyanoferrate films is discussed, as well as the adsorption isotherms and kinetics properties.

\section{Experimental}

\subsection{Materials and apparatus}

All reagents, such as $\mathrm{Cu}\left(\mathrm{NO}_{3}\right)_{2} \cdot x \mathrm{H}_{2} \mathrm{O}, \quad \mathrm{Ni}\left(\mathrm{NO}_{3}\right)_{2} \cdot 6 \mathrm{H}_{2} \mathrm{O}$, $\mathrm{Co}\left(\mathrm{NO}_{3}\right)_{2} \cdot 6 \mathrm{H}_{2} \mathrm{O}, \quad \mathrm{LiNO}_{3}, \mathrm{~K}_{3}\left[\mathrm{Fe}(\mathrm{CN})_{6}\right], \mathrm{K}_{3}\left[\mathrm{Fe}(\mathrm{CN})_{6}\right] \cdot 3 \mathrm{H}_{2} \mathrm{O}$ and $\mathrm{KNO}_{3}$, used in the operations were of analytical grade or better without further purification. Ultrapure water $(18 \mathrm{M} \Omega \mathrm{cm})$ was used throughout all the operations. All the experiments were carried out at room temperature.

Ion concentrations were determined by inductively coupled plasma mass spectrometry (ICP-MS, Thermo Fisher Scientific iCAP Q, America). The surface morphologies of $\mathrm{Cu}_{x} \mathrm{Ni}_{y} \mathrm{HCF}$ films were observed by a field-emission scanning electron microscope (FE-SEM, Hitachi SU-8010, Japan). Their structures and compositions were characterized by X-ray powder diffractometry (XRD, Rigaku SmartLab, Japan) and Fourier transform infrared spectroscopy (FTIR, Bruker Vertex 70, Germany). Cyclic voltammetry of $\mathrm{Cu}_{x} \mathrm{Ni}_{y} \mathrm{HCF}$ electrode films was performed by using an electrochemical analyzer (Chen Hua CHI660e, China).

\subsection{Preparation of modified electrodes}

As described in our previous studies, ${ }^{25}$ h-MHCF nanoparticle inks with different metal molar ratios were prepared by wet chemical coprecipitation. Firstly, mixed solutions with different molar ratios $(x: y=1: 4,1: 2,1: 1,2: 1$, and $4: 1)$ were obtained from $\mathrm{Cu}\left(\mathrm{NO}_{3}\right)_{2} \cdot x \mathrm{H}_{2} \mathrm{O}$ and $\mathrm{Ni}\left(\mathrm{NO}_{3}\right)_{2} \cdot 6 \mathrm{H}_{2} \mathrm{O}$, to which a solution of $\mathrm{K}_{3}\left[\mathrm{Fe}(\mathrm{CN})_{6}\right]$ was added; the reactant mole ratio of total metal nitrates to $\mathrm{K}_{3}\left[\mathrm{Fe}(\mathrm{CN})_{6}\right]$ was kept at $3: 2$. Secondly, one group of parallel samples were dried in an oven at $60{ }^{\circ} \mathrm{C}$ to obtain powder samples for subsequent chemical analysis and characterizations. The remaining samples were surface-treated by $\mathrm{K}_{4}\left[\mathrm{Fe}(\mathrm{CN})_{6}\right] \cdot 3 \mathrm{H}_{2} \mathrm{O}$ to dissolve well in water. Thirdly, the $5 \%$ (ratio of mass to volume) ink-like solutions of nanoparticles were prepared and shaken for one week $\left(25{ }^{\circ} \mathrm{C}, 150 \mathrm{rpm}\right)$. Indium tin oxide (ITO) was washed with acetone as a support substance, and $\mathrm{Cu}_{x} \mathrm{Ni}_{y} \mathrm{HCF}$ nanoparticle inks were coated on it using a KW-4A spin-coater instrument $(2000 \mathrm{rpm}$ for $10 \mathrm{~s}$ followed by $2500 \mathrm{rpm}$ for another $10 \mathrm{~s}$ ). Finally, the modified electrodes were dried in an oven at $120^{\circ} \mathrm{C}$ for $2 \mathrm{~h}$.

\subsection{Characterization}

In order to investigate the composition ratios, the prepared $\mathrm{Cu}_{x} \mathrm{Ni}_{y} \mathrm{HCF}$ powders were decomposed in aqua regia by using microwave digestion. After microwave digestion, dilution and filtration, the elements were determined by ICP-MS. The obtained $x: y$ ratio is linearly fitted to the theoretical values in the synthesis process. The fitness $\left(R^{2}\right)$ is given by eqn (1):

$$
R^{2}=\frac{\sum\left(y^{\prime}-y^{*}\right)^{2}}{\sum\left(y^{\prime}-y\right)^{2}}
$$

$y^{*}, y$ and $y^{\prime}$ stand for the theoretical ratio values, the actual ratio values and the mean value of $y$, respectively. For convenience, the ratio of $x: y$ is converted to the percentage of $\mathrm{Cu}\left(W_{\mathrm{Cu}}\right)$ in the nanoparticle films, with the following expression:

$$
W_{\mathrm{Cu}}=\frac{n_{\mathrm{Cu}}}{n_{\mathrm{Cu}}+n_{\mathrm{Ni}}} \times 100 \%
$$

where $n_{\mathrm{Cu}}$ and $n_{\mathrm{Ni}}$ stand for the number of moles of $\mathrm{Cu}$ and $\mathrm{Ni}$ in $\mathrm{Cu}_{x} \mathrm{Ni}_{y} \mathrm{HCF}$ nanoparticle films, respectively.

A three-electrode system was used with a saturated calomel electrode ( $\mathrm{SCE}, \mathrm{Hg} / \mathrm{Hg}_{2} \mathrm{Cl}_{2} / \mathrm{KCl}$ ) as the reference electrode, a Pt wire as the counter electrode and the ITO plate loaded with nanoparticle films as the working electrode. The cyclic voltammograms (CVs) of $\mathrm{Cu}_{x} \mathrm{Ni}_{y} \mathrm{HCF}$ films in the different cation solutions were obtained, using a CHI660e electrochemical analyzer. The electrochemical properties of $\mathrm{Cu}_{x} \mathrm{Ni}_{y} \mathrm{HCF}$ nanoparticle films were characterized by $\mathrm{CV}$, formal potential $\left(E_{\mathrm{f}}\right)$, accumulated quantity of electric charge $(Q)$ and surface coverage of redox-active sites $(T) . E_{\mathrm{f}}$ is calculated as half of the sum of potentials of the anodic $\left(E_{\mathrm{pa}}\right)$ and cathodic $\left(E_{\mathrm{pc}}\right)$ current peak. $Q$ is the charge obtained by integrating the cathodic peak after subtraction of the background. The calculation equation of $\Gamma$ is as follows: 


$$
\Gamma=\frac{Q}{n \times F \times A}
$$

$Q$ is obtained by integrating the cathodic peak from the 2 nd cycle under the background correction at a scan rate of $0.05 \mathrm{~V}$ $\mathrm{s}^{-1}$, and other symbols have their usual meanings. The electrodes used here are modified by $3 \%$ ink.

The stability of the $\mathrm{Cu}_{x} \mathrm{Ni}_{y} \mathrm{HCF}$ films was investigated by long-term potential cycling (500 cycles), expressed by the rate of decrease $\left(R_{\mathrm{d}}\right)$ of the integrated Faraday charge $Q$ with the increase in the number of cycles.

$$
R_{\mathrm{d}}=\frac{Q_{1}-Q_{n}}{Q_{1}} \times 100 \%
$$

$Q_{1}$ and $Q_{n}$ stand for the integrated charge recorded from the 1st and $n$th scan cycles, respectively.

\subsection{Electrochemical adsorption of $\mathrm{Co}^{2+}$}

2.4.1 Removal efficiency. $\mathrm{Co}^{2+}$ removal was performed in a three-electrode cell containing $40 \mathrm{~mL}$ solutions stirred at $500 \mathrm{rpm}$ by a magnetic stirrer (DL Instruments Ltd., MS-H280Pro, China). The films were firstly pretreated by an applied

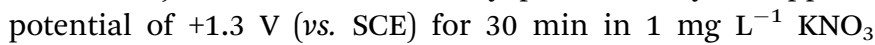
solution to discharge the residual $\mathrm{K}^{+}$during the surface treatment. The relevant reaction is as follows:

$$
\mathrm{K}_{4}\left[\mathrm{Fe}^{\mathrm{II}}(\mathrm{CN})_{6}\right] \rightarrow 4 \mathrm{~K}^{+}+\left[\mathrm{Fe}^{\mathrm{III}}(\mathrm{CN})_{6}\right]^{3-}+\mathrm{e}^{-}
$$

Afterwards, the films were washed with ultrapure water and transferred to $1 \mathrm{mg} \mathrm{L}^{-1} \mathrm{Co}^{2+}$ solution to adsorb $\mathrm{Co}^{2+}$ by applying a reduction potential of $-0.4 \mathrm{~V}$ ( $v s$. SCE).

$$
\mathrm{M}_{3}\left[\mathrm{Fe}^{\mathrm{III}}(\mathrm{CN})_{6}\right]_{2}+2 \mathrm{e}^{-}+\mathrm{Co}^{2+} \rightarrow \mathrm{CoM}_{3}\left[\mathrm{Fe}^{\mathrm{II}}(\mathrm{CN})_{6}\right]_{2}
$$

Contrast tests were conducted at the same time without applying potentials.

The results of electrochemical adsorption were given as removal efficiency $(R)$, which was calculated according to eqn (7):

$$
R=\frac{C_{0}-C_{t}}{C_{0}} \times 100 \%
$$

where $C_{0}\left(\mathrm{mg} \mathrm{L}^{-1}\right)$ and $C_{t}\left(\mathrm{mg} \mathrm{L}^{-1}\right)$ stand for the $\mathrm{Co}^{2+}$ concentration at the initial stage and at time $t$, respectively.

2.4.2 Isotherm and kinetic studies. Batch adsorption experiments were conducted in $\mathrm{Co}^{2+}$ solutions at various initial concentrations $\left(0.5 \mathrm{mg} \mathrm{L}^{-1}, 1 \mathrm{mg} \mathrm{L}^{-1}, 2 \mathrm{mg} \mathrm{L}^{-1}, 5 \mathrm{mg} \mathrm{L}^{-1}\right.$, and $10 \mathrm{mg} \mathrm{L}^{-1}$ ) to investigate the adsorption mechanism. The batch adsorption data were fitted with the Langmuir model (8), and the Freundlich isotherm model (9).

$$
\begin{gathered}
\frac{C_{\mathrm{e}}}{Q_{\mathrm{e}}}=\frac{1}{Q_{\mathrm{m}} \times K_{\mathrm{L}}}+\frac{C_{\mathrm{e}}}{Q_{\mathrm{m}}} \\
\ln Q_{\mathrm{e}}=\ln K_{\mathrm{F}}+\frac{\ln C_{\mathrm{e}}}{n}
\end{gathered}
$$

Here, $C_{\mathrm{e}}\left(\mathrm{mg} \mathrm{L}^{-1}\right)$ is the equilibrium concentration; $Q_{\mathrm{e}}(\mathrm{mg}$ $\left.\mathrm{cm}^{-2}\right)$ and $Q_{\mathrm{m}}\left(\mathrm{mg} \mathrm{cm}^{-2}\right)$ are the saturation adsorption capacity and the maximum adsorption capacity at the pseudoequilibrium, respectively. $K_{\mathrm{L}}, K_{\mathrm{F}}$ and $n$ (dimensionless) are the adsorption isotherm constants for the Langmuir isotherm and the Freundlich isotherm.

The intraparticle diffusion model, pseudo-first-order and pseudo-second-order adsorption kinetic models were used to analyze the dynamic adsorption process, as represented by eqn (10)-(12), respectively.

$$
\begin{gathered}
Q_{t}=k_{\mathrm{p}, \mathrm{i}} \times t^{0.5}+C_{\mathrm{i}} \\
\ln \left(Q_{\mathrm{e}}-Q_{\mathrm{t}}\right)=\ln Q_{\mathrm{e}}-k_{1} \times t \\
\frac{t}{Q_{t}}=\frac{1}{k_{2} Q_{\mathrm{e}}{ }^{2}}+\frac{t}{Q_{\mathrm{e}}}
\end{gathered}
$$

where, $Q_{\mathrm{e}}\left(\mathrm{mg} \mathrm{cm}^{-2}\right)$ and $Q_{t}\left(\mathrm{mg} \mathrm{cm}^{-2}\right)$ are the adsorption amounts of $\mathrm{Co}^{2+}$ at the adsorption equilibrium and time $t$, respectively. $k_{\mathrm{p}, \mathrm{i}}$ (i represents the different stages), $k_{1}$ and $k_{2}$ are the rate constants. $C_{\mathrm{i}}$ is the intercept at different stages.

\section{Results and discussion}

\subsection{Characterizations of $\mathrm{Cu}_{x} \mathrm{Ni}_{y} \mathrm{HCF}$ nanoparticle films}

3.1.1 Component analysis. The actual contents of $\mathrm{Cu}$ and $\mathrm{Ni}$ of the prepared $\mathrm{Cu}_{x} \mathrm{Ni}_{y} \mathrm{HCFs}$ were determined by ICP-MS, as listed in Table 1.

The fitness of the theoretical and actual values is 0.9840 , showing that the two sets of values are very close. In other words, unlike electrodeposition, ${ }^{33,34}$ the $x: y$ ratios in the $\mathrm{Cu}_{x^{-}}$ $\mathrm{Ni}_{y} \mathrm{HCF}$ nanoparticle films can be controlled by the preparation method. This is because hexacyanoferrate (II) ions are generated firstly in the vicinity of the electrode surface and then react primarily with one kind of metal ion in the electrolyte ${ }^{27}$ when prepared by electrodeposition. For coprecipitation, metal ions and hexacyanoferrate (III) ions have been mixed and reacted evenly during the preparation stage of the ink. The results mean that $\mathrm{Cu}_{x} \mathrm{Ni}_{y} \mathrm{HCF}$ films with appropriate metal ratios can be synthesized as required.

3.1.2 Morphology. The surface structures of the nanoparticle films are shown in Fig. 1. It is found that NiHCF film exhibits a compact structure consisting of homogeneous nanoparticles, with the formation of evident cracks and the agglomeration of NiHCF nanoparticles. While abundant pores obviously grow on CuHCF films, which might facilitate the mass transfer and diffusion rate of ions within films. ${ }^{25}$ The nanoparticle size of CuHCF films is obviously larger than that of NiHCF films, which is consistent with previous research results. ${ }^{26,35}$ The nanoparticle size and porosity of $\mathrm{Cu}_{x} \mathrm{Ni}_{y} \mathrm{HCF}$ films varied from pure NiHCF films to pure CuHCF films. The

Table 1 Atomic number of $\mathrm{Cu}$ and $\mathrm{Ni}$ in $\mathrm{Cu}_{x} \mathrm{Ni}_{y} \mathrm{HCF}$ nanoparticles

\begin{tabular}{llllll}
\hline$x: y$ & $4: 1$ & $2: 1$ & $1: 1$ & $1: 2$ & $1: 4$ \\
\hline $\mathrm{Cu}$ & 0.6282 & 0.5263 & 0.3860 & 0.2562 & 0.0792 \\
$\mathrm{Ni}$ & 0.1704 & 0.2839 & 0.4130 & 0.6022 & 0.3726
\end{tabular}




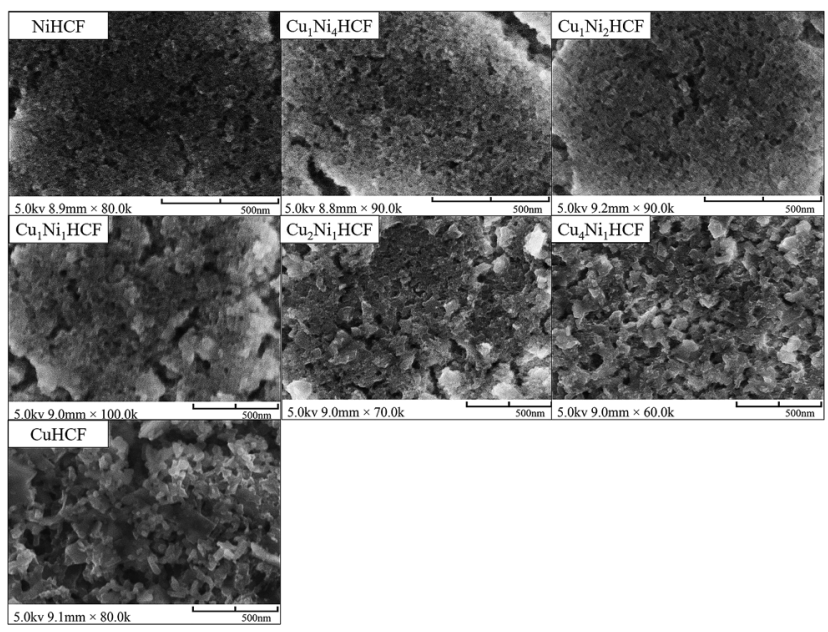

Fig. 1 FE-SEM images of $\mathrm{Cu}_{x} \mathrm{Ni}_{y} \mathrm{HCF}$ nanoparticle films with different metal ratios $\left(M_{1}: M_{2}\right)$.

presence of $\mathrm{Ni}$ had a significant effect on the morphology of $\mathrm{Cu}_{x} \mathrm{Ni}_{y} \mathrm{HCF}$ films. $\mathrm{Cu}_{4} \mathrm{Ni}_{1} \mathrm{HCF}, \mathrm{Cu}_{2} \mathrm{Ni}_{1} \mathrm{HCF}, \mathrm{Cu}_{1} \mathrm{Ni}_{1} \mathrm{HCF}, \mathrm{Cu}_{1}-$ $\mathrm{Ni}_{2} \mathrm{HCF}$ and $\mathrm{Cu}_{1} \mathrm{Ni}_{4} \mathrm{HCF}$ displayed particulate agglomeration and stratification, which were similar to that observed in NiHCF films.

3.1.3 Structure. In order to further explore the effect of $x: y$ ratio on the properties of $\mathrm{Cu}_{x} \mathrm{Ni}_{y} \mathrm{HCFs}, \mathrm{Cu}_{x} \mathrm{Ni}_{y} \mathrm{HCF}$ powders were characterized by XRD and FTIR. As shown in Fig. 2, all $\mathrm{Cu}_{x} \mathrm{Ni}_{y} \mathrm{HCFs}$ have four predominant $2 \theta$ peaks in the range of 17$40^{\circ}$ corresponding to the ( $\left(\begin{array}{lll}2 & 0 & 0\end{array}\right),\left(\begin{array}{lll}2 & 2 & 0\end{array}\right),\left(\begin{array}{lll}4 & 0 & 0\end{array}\right)$ and $\left(\begin{array}{lll}4 & 2 & 0\end{array}\right)$ diffraction planes of a face-centered-cubic lattice structure, which are very consistent with the ref. 18,36 and $37.2 \theta$ values obtained for h-MHCFs fall between the NiHCF and CuHCF peak positions. With an increasing content of copper, the diffraction peak position of $\mathrm{Cu}_{x} \mathrm{Ni}_{y} \mathrm{HCFs}$ shows a slight shift from NiHCF to CuHCF.

The crystallite size $(D)$ can be deduced from the diffraction peak according to Sherrer's formula:

$$
D=\frac{K \times \lambda}{\beta \times \cos \theta}
$$

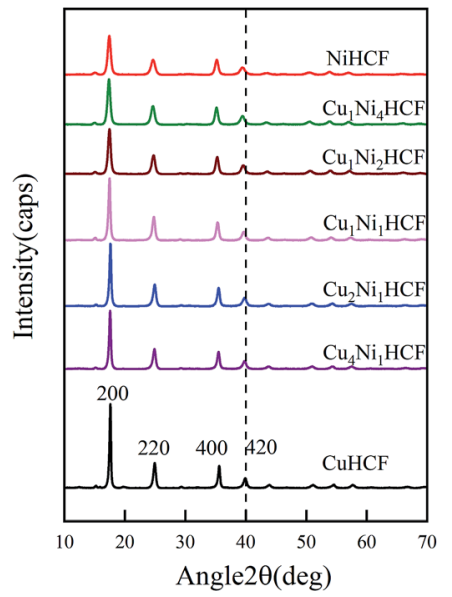

Fig. 2 XRD patterns of $\mathrm{Cu}_{x} \mathrm{Ni}_{y} \mathrm{HCF}$ powders. where $K$ is the shape factor, $\lambda$ is the X-ray wavelength (0.154056 $\mathrm{nm}), \beta$ is the full width at half maximum of the diffraction peak, and $\theta$ is the Bragg diffraction angle. As presented in Fig. 3, the crystallite sizes of NiHCF and CuHCF are estimated to be about $15 \mathrm{~nm}$ and $30 \mathrm{~nm}$, respectively; the sizes of $\mathrm{Cu}_{x} \mathrm{Ni}_{y} \mathrm{HCFs}$ at different ratios of $\mathrm{Cu} / \mathrm{Ni}$ are in between these values. The value of $D$ rarely changes with the increase of copper content when $W_{\mathrm{Cu}}<30 \%$; then it increases linearly with the $W_{\mathrm{Cu}}$ values. We suppose that the lattice of NiHCF (as shown in Fig. 4a) is practically unchanged when $W_{\mathrm{Cu}}<33 \% . \mathrm{Cu}^{2+}$ inset in NiHCF lattice instead of $\mathrm{K}^{+}$as countercations to maintain the electrical neutrality of the structure in a situation such as that exhibited by Fig. $4 \mathrm{~b}$. The crystal structure begins to change as the $\mathrm{Cu}$ content increases to around 33\%, while the $\mathrm{Cu}$ replace part of the Ni to occupy the lattice positions illustrated by Fig. 4c.

Fig. 5 illustrates the FTIR spectra of $\mathrm{Cu}_{x} \mathrm{Ni}_{y} \mathrm{HCF}$ powders. In particular, there is a small shoulder at $2165.21 \mathrm{~cm}^{-1}$ of NiHCF, while the other samples show only one major peak in the vicinity of $2096 \mathrm{~cm}^{-1}$. The other bands of $\mathrm{Cu}_{x} \mathrm{Ni}_{y} \mathrm{HCFs}$ are very

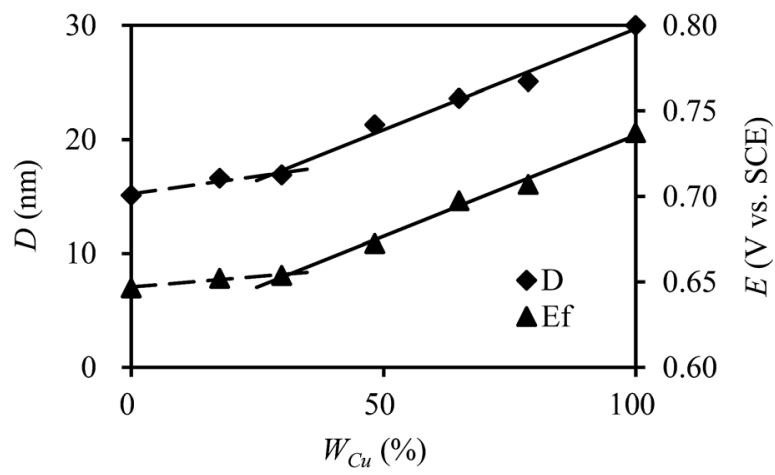

Fig. 3 Crystallite size $(D)$ and formal potential $\left(E_{f}\right)$ of $\mathrm{Cu}_{x} \mathrm{Ni}_{y} \mathrm{HCFs}$ versus molar content of $\mathrm{Cu}\left(W_{\mathrm{Cu}}\right)$.

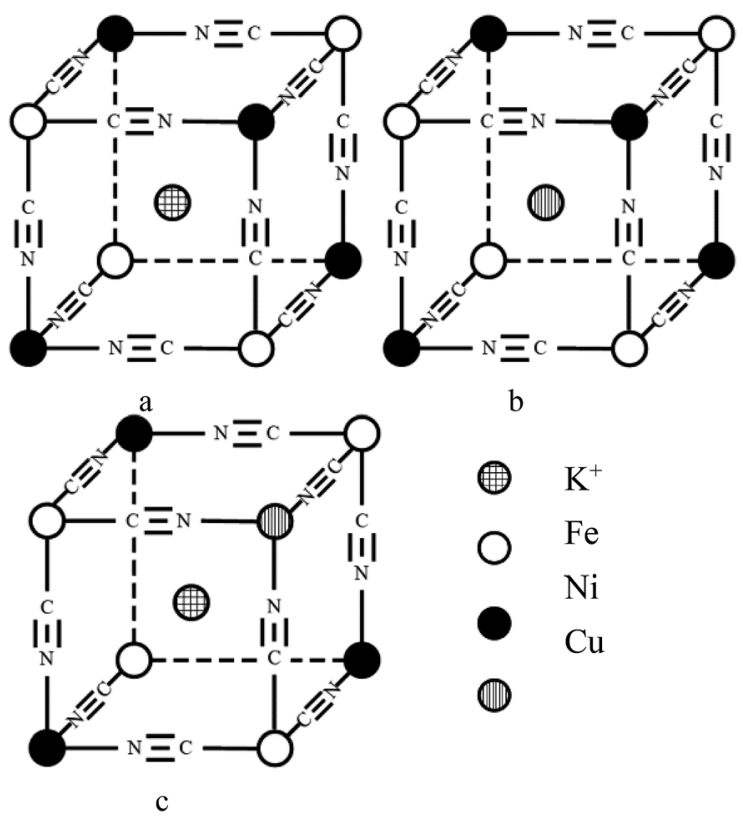

Fig. 4 Schematic of $1 / 8$ cell structure of $\operatorname{MHCF}(\mathrm{M}: \mathrm{Cu}, \mathrm{Ni})$. 


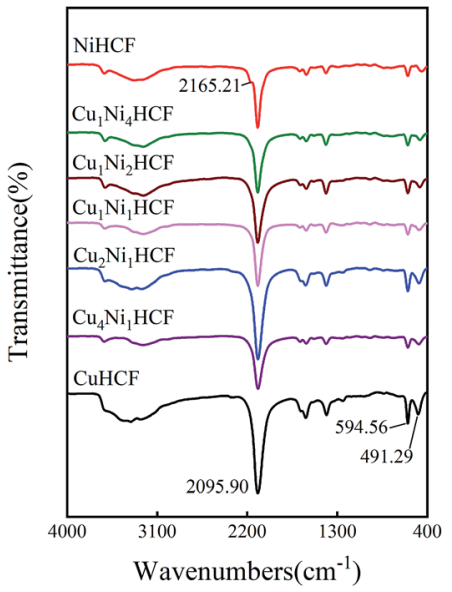

Fig. 5 FITR spectrum of $\mathrm{Cu}_{x} \mathrm{Ni}_{y} \mathrm{HCF}$ powders.

close to each other, owing to the similar absorption peaks of NiHCF and CuHCF. The broad band at around $3330 \mathrm{~cm}^{-1}$ refers to the $\mathrm{O}-\mathrm{H}$ stretching vibrations. ${ }^{38}$ The vibrational band near $2096 \mathrm{~cm}^{-1}$ corresponds to the stretching vibration absorption band of the $-\mathrm{C} \equiv \mathrm{N}$ group. ${ }^{39,40}$ The bands in the region of $1400-$ $1680 \mathrm{~cm}^{-1}$ are related to the asymmetric and symmetric stretching vibrations of $\mathrm{COO}^{-}$groups. ${ }^{41,42}$ The stretching vibration absorption band of the free $-\mathrm{C} \equiv \mathrm{N}$ is at about $2060 \mathrm{~cm}^{-1}$ in aqueous solution; ${ }^{43}$ the blue shift of the absorption band observed together with the two smaller peaks at about $595 \mathrm{~cm}^{-1}$ and $491 \mathrm{~cm}^{-1}$ are attributed to the formation of $\mathrm{Fe}-$ $\mathrm{CN}-\mathrm{M} \cdot{ }^{39,44}$

3.1.4 Electrochemical properties. CV plots with distinct redox couple peaks of $\mathrm{Cu}_{x} \mathrm{Ni}_{y} \mathrm{HCF}$ films in $0.5 \mathrm{M} \mathrm{K}^{+}$solution are shown in Fig. 6a. One set of symmetrical redox couples of CuHCF films is around $0.723 \mathrm{~V}$, while the voltammetric patterns of the NiHCF films have two pairs of redox peaks at a lower potential range of $0.45-0.65 \mathrm{~V}$, assigned to the presence of two phases within the NiHCF films. ${ }^{45,46}$ The intensity and location of the response curve peaks of $\mathrm{Cu}_{x} \mathrm{Ni}_{y} \mathrm{HCFs}$ depend on the value of $x: y$, which is consistent with the change in structure from XRD and FTIR results. As indicated in a previous study, ${ }^{47} \mathrm{Cu}_{x} \mathrm{Ni}_{y} \mathrm{HCF}$ is a new phase rather than a simple mixture of CuHCF and NiHCF. The typical CV response of each $\mathrm{Cu}_{x} \mathrm{Ni}_{y} \mathrm{HCF}$ is attributed to its respective unique structure. In particular, two sets of redox peaks of $\mathrm{Cu}_{1} \mathrm{Ni}_{4} \mathrm{HCF}$ and $\mathrm{Cu}_{1} \mathrm{Ni}_{2} \mathrm{HCF}$ are similar to $\mathrm{NiHCF}$, and, the redox peaks at $0.45 \mathrm{~V}$ are severely weakened, which might be because of their special structures, as illustrated in Fig. $4 \mathrm{~b}$. The $E_{\mathrm{f}}$ values of $\mathrm{Cu}_{x} \mathrm{Ni}_{y} \mathrm{HCF}$ films were plotted as a function of $W_{\mathrm{Cu}}$, as approximated in Fig. 3. At a low molar fractions of $\mathrm{Cu}$, the $E_{\mathrm{f}}$ value hardly changes with the addition of
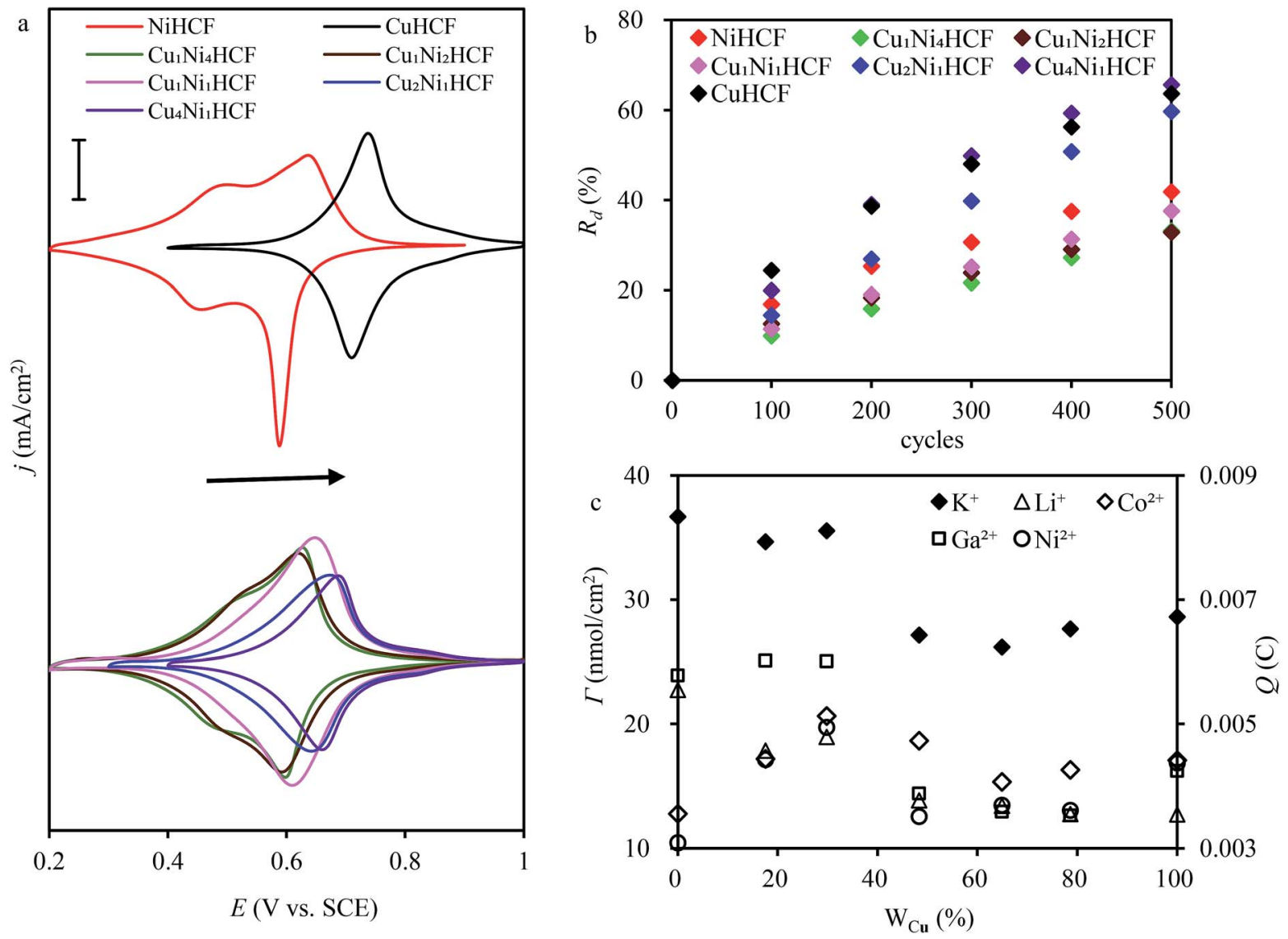

Fig. 6 (a) Cyclic voltammograms of $\mathrm{Cu}_{x} \mathrm{Ni}_{y} \mathrm{HCF}$ modified electrodes (scan rate: $0.005 \mathrm{~V} \mathrm{~s}{ }^{-1}$; electrode area: $15 \mathrm{~mm} \times 12.5 \mathrm{~mm}$ ); (b) rate of decrease $\left(R_{\mathrm{d}}\right)$ of the cathodic integrated charge $v s$. the number of sweeping cycles. (Scan rate: $0.05 \mathrm{~V} \mathrm{~s}{ }^{-1}$; electrode area: $15 \mathrm{~mm} \times 12.5 \mathrm{~mm}$ ); (c) surface coverage and integrated Faraday charge in different electrolytes $\left(c\left(\mathrm{~K}^{+}\right)=0.5 \mathrm{M}, c\left(\mathrm{Li}^{+}\right)=0.5 \mathrm{M}, c\left(\mathrm{Co}^{2+}\right)=0.5 \mathrm{M}, c\left(\mathrm{Ga}^{2+}\right)=0.1 \mathrm{M}, c\left(\mathrm{Ni}^{2+}\right)=\right.$ $0.5 \mathrm{M}$. Scan rate: $0.05 \mathrm{~V} \mathrm{~s}^{-1}$; electrode area: $15 \mathrm{~mm} \times 12.5 \mathrm{~mm}$ ). 
$\mathrm{Cu}$, then depends linearly on the content of copper when $W_{\mathrm{Cu}}$ rises to about $33 \%$. These observations confirm our previous hypothesis that $\mathrm{Cu}$ exists in two forms: as countercations substituted for $\mathrm{K}^{+}$, under which condition the $E_{\mathrm{f}}$ is close to that of NiHCF ${ }^{48}$ or occupying lattice positions instead of Ni. This is similar to the electrodeposited films studied by Kulesza et al. ${ }^{27} \mathrm{It}$ can be found from Fig. 6 a that the redox peaks at more negative potential disappear when $W_{\mathrm{Cu}}>30 \%$, which also demonstrates that $\mathrm{Cu}$ started to occupy positions of the lattice.

The ratio value of cathodic current to anodic peak $\left(i_{\mathrm{pc}} / i_{\mathrm{pa}}\right)$ approaches one, implying the reversibility of the electrochemical redox reaction. The existence of $\mathrm{Cu}$ greatly improved the property of NiHCF films in this respect. The long-term CV of $\mathrm{Cu}_{x} \mathrm{Ni}_{y} \mathrm{HCF}$ films was carried out in $0.5 \mathrm{M} \mathrm{K}^{+}$at a scan rate of $0.05 \mathrm{~V} \mathrm{~s}^{-1}$ to study the stability of $\mathrm{Cu}_{x} \mathrm{Ni}_{y} \mathrm{HCFs}$. $R_{\mathrm{d}}$ values were plotted against the cycle numbers, as depicted in Fig. $6 \mathrm{~b}$. NiHCF films show comparatively high stability compared with CuHCF films, which is in accord with the materials synthesized previously from chlorides. ${ }^{25}$ The stability of $\mathrm{Cu}_{x} \mathrm{Ni}_{y} \mathrm{HCF}$ films increases with a decrease in $x: y$ values in the order: $\mathrm{Cu}_{4} \mathrm{Ni}_{1} \mathrm{HCF}$ $<\mathrm{Cu}_{2} \mathrm{Ni}_{1} \mathrm{HCF}<\mathrm{Cu}_{1} \mathrm{Ni}_{1} \mathrm{HCF}<\mathrm{Cu}_{1} \mathrm{Ni}_{2} \mathrm{HCF}<\mathrm{Cu}_{1} \mathrm{Ni}_{4} \mathrm{HCF}$. It is noteworthy that the cycling stabilities of $\mathrm{Cu}_{1} \mathrm{Ni}_{4} \mathrm{HCF}, \mathrm{Cu}_{1} \mathrm{Ni}_{2}$ HCF and $\mathrm{Cu}_{1} \mathrm{Ni}_{1} \mathrm{HCF}$ films are notably better than that of NiHCF films, indicating that the stability of $\mathrm{Cu}_{x} \mathrm{Ni}_{y} \mathrm{HCF}$ films will be enhanced on the basis of NiHCF films when the copper content of copper is lower than or even equal to the nickel content. In contrast, the cycling stability will get worse when the proportion of copper is higher.

The results of the surface coverage $\Gamma$ calculated from the integrated charge in $0.5 \mathrm{M} \mathrm{K}^{+}$solution are shown in Fig. 6c. The $\Gamma$ value of NiHCF films is apparently higher than that of CuHCF films. The $\Gamma$ values of $\mathrm{Cu}_{1} \mathrm{Ni}_{4} \mathrm{HCF}$ films and $\mathrm{Cu}_{1} \mathrm{Ni}_{2} \mathrm{HCF}$ films are 1.2-1.4 times as much as the $\Gamma$ values of other $\mathrm{Cu}_{x} \mathrm{Ni}_{y} \mathrm{HCFs}$.

\subsection{Electrochemical adsorption of cations}

3.2.1 Electrochemical behaviors in cationic solutions. In addition to $\mathrm{K}^{+}$solution, the $\mathrm{CV}$ responses of $\mathrm{Cu}_{x} \mathrm{Ni}_{y} \mathrm{HCF}$ films in $\mathrm{Li}^{+}, \mathrm{Co}^{2+}, \mathrm{Ni}^{2+}$ and $\mathrm{Ga}^{2+}$ solutions are also discussed. The electric quantity $Q$ of the reduction current of $\mathrm{Cu}_{x} \mathrm{Ni}_{y} \mathrm{HCF}$ films in the $\mathrm{Li}^{+}, \mathrm{Co}^{2+}, \mathrm{Ni}^{2+}$ and $\mathrm{Ga}^{2+}$ solutions were integrated (as shown in Fig. 6c). The $\mathrm{Cu}_{1} \mathrm{Ni}_{2} \mathrm{HCF}$ films show the maximum value of the integrated charge in hybrid films, which may be bound up with the $\Gamma$.

The fine CV responses imply the possibility of electrochemical adsorption of metal cations. In the electrochemical adsorption experiment, $\mathrm{Co}^{2+}$ were effectively removed by $\mathrm{Cu}_{x^{-}}$ $\mathrm{Ni}_{y}$ HCFs. That is why $\mathrm{Co}^{2+}$ was chosen to carry out the experiment on the electrochemical adsorption behavior of $\mathrm{Cu}_{x} \mathrm{Ni}_{y} \mathrm{HCF}$ films. The $\mathrm{Cu}_{1} \mathrm{Ni}_{2} \mathrm{HCF}$ films were used for comparison with CuHCF films and NiHCF films since they have excellent electrochemical performances. In order to study information about the mechanism, CV and electrochemical impedance spectroscopy (EIS) experiments were conducted. The CVs of $\mathrm{Cu}_{x} \mathrm{Ni}_{y} \mathrm{HCF}$ modified electrodes at various sweep rates from 0.005 to $0.15 \mathrm{~V}$ $\mathrm{s}^{-1}$ in $0.5 \mathrm{M} \mathrm{Co}^{2+}$ solutions are shown in Fig. 7a-c. The logarithmic cathodic peak current increases linearly with an increase in the logarithmic scan rate (shown as insets). The slopes of the $\mathrm{Cu}_{x} \mathrm{Ni}_{y} \mathrm{HCF}$ films are $0.75-0.88$ (listed in Table $\mathrm{S} 1 \dagger)$, indicating that the reaction at the thin films is controlled by an ion diffusion process and a surface electron transfer process, with a tendency towards the latter. ${ }^{49}$ The $\Delta E$ gradually increases with the variation in the scan rate, indicating a limitation arising from the charge-transfer kinetics ${ }^{50}$ which weakened the reversibility. ${ }^{51}$

The Nyquist plots (Fig. 7d) are composed of a distorted semicircle in the high-frequency region assigned to the chargetransfer reaction of the electrode and a linear part at the lowfrequency end due to a diffusion-controlled process. ${ }^{29,52}$ The CuHCF film is characterized by the lowest diameter of the semicircle, standing for the quickest electron transfer rate. ${ }^{53}$ The charge transfer resistance decreases in the order: $\mathrm{Cu}_{1} \mathrm{Ni}_{2}$ $\mathrm{HCF}>\mathrm{NiHCF}>\mathrm{CuHCF}$.

3.2.2 Removal efficiency of $\mathbf{C o}^{2+}$. Fig. 8a compares the results of $\mathrm{Co}^{2+}$ adsorption in electrochemical and conventional systems. The removal efficiency of electrochemical adsorption is 3-4 times higher than that of conventional adsorption, verifying that an electrochemical removal process had played an important role. And, the process of $\mathrm{Co}^{2+}$ adsorption involved both surface adsorption and cation intercalation/ deintercalation.

The electrochemical adsorption capacity of CuHCF films is much higher than that of NiHCF films, verifying the results of integrated charge and EIS. The high adsorption capacity can be interpreted by the large lattice size of CuHCF. This is consistent with the fact that the sorption capacity of CuHCF is larger than that of NiHCF, as mentioned by Thierry et al. ${ }^{54}$ It is remarkable that the equilibrium removal efficiency of $\mathrm{Cu}_{1} \mathrm{Ni}_{2} \mathrm{HCF}$ films is higher than that of NiHCF films, and slightly lower than that of CuHCF films, which may due to the well-ordered porous structures of CuHCF films. The redox peaks of CuHCF film in $\mathrm{Co}^{2+}$ solutions are sharper than those of $\mathrm{Cu}_{1} \mathrm{Ni}_{2} \mathrm{HCF}$ film, indicating a faster dynamic process. The cycling stability of $\mathrm{Cu}_{1} \mathrm{Ni}_{2} \mathrm{HCF}$ film is obviously better than that of CuHCF film, when the equilibrium removal efficiency of $\mathrm{Cu}_{1} \mathrm{Ni}_{2} \mathrm{HCF}$ film is close to that of CuHCF film. That is why we chose $\mathrm{Cu}_{1} \mathrm{Ni}_{2} \mathrm{HCF}$ for the next step.

The crystal structure and surface morphology of $\mathrm{Cu}_{1} \mathrm{Ni}_{2} \mathrm{HCF}$ film before and after removing $\mathrm{Co}^{2+}$ were investigated by XRD and SEM; the results are depicted in Fig. $8 \mathrm{~b}$ and c. Compared with the peaks of $\left(\mathrm{In}_{1.88} \mathrm{Sn}_{0.12}\right) \mathrm{O}_{3}$ (PDF \# 89-4598) coated on substrates, the new peaks generated at around $17.95^{\circ}$ and $25.35^{\circ}$ and the sharper peaks at $35.48^{\circ}$ and $37.65^{\circ}$ are caused by $\mathrm{Cu}_{1} \mathrm{Ni}_{2} \mathrm{HCF}$ film. There is no significant change in the results of SEM and XRD after $\mathrm{Co}^{2+}$-loading, indicating that the structure of the nanocrystals had not been changed by the adsorption process. The concentrations of $\mathrm{Cu}^{2+}$ and $\mathrm{Ni}^{2+}$ before and after pretreating the films were determined by ICP-MS (Fig. S2 $\dagger$ ). The results show that there is no significant release of $\mathrm{Cu}^{2+}$ or $\mathrm{Ni}^{2+}$ from the films, indicating that the prepared nanoparticle films were stable as well. These phenomena are consistent with the expected cation insertion process, during which the essential feature of crystal structure is preserved. This may also due to the dilute solution and trace amount of $\mathrm{Co}^{2+}$ adsorbed on 

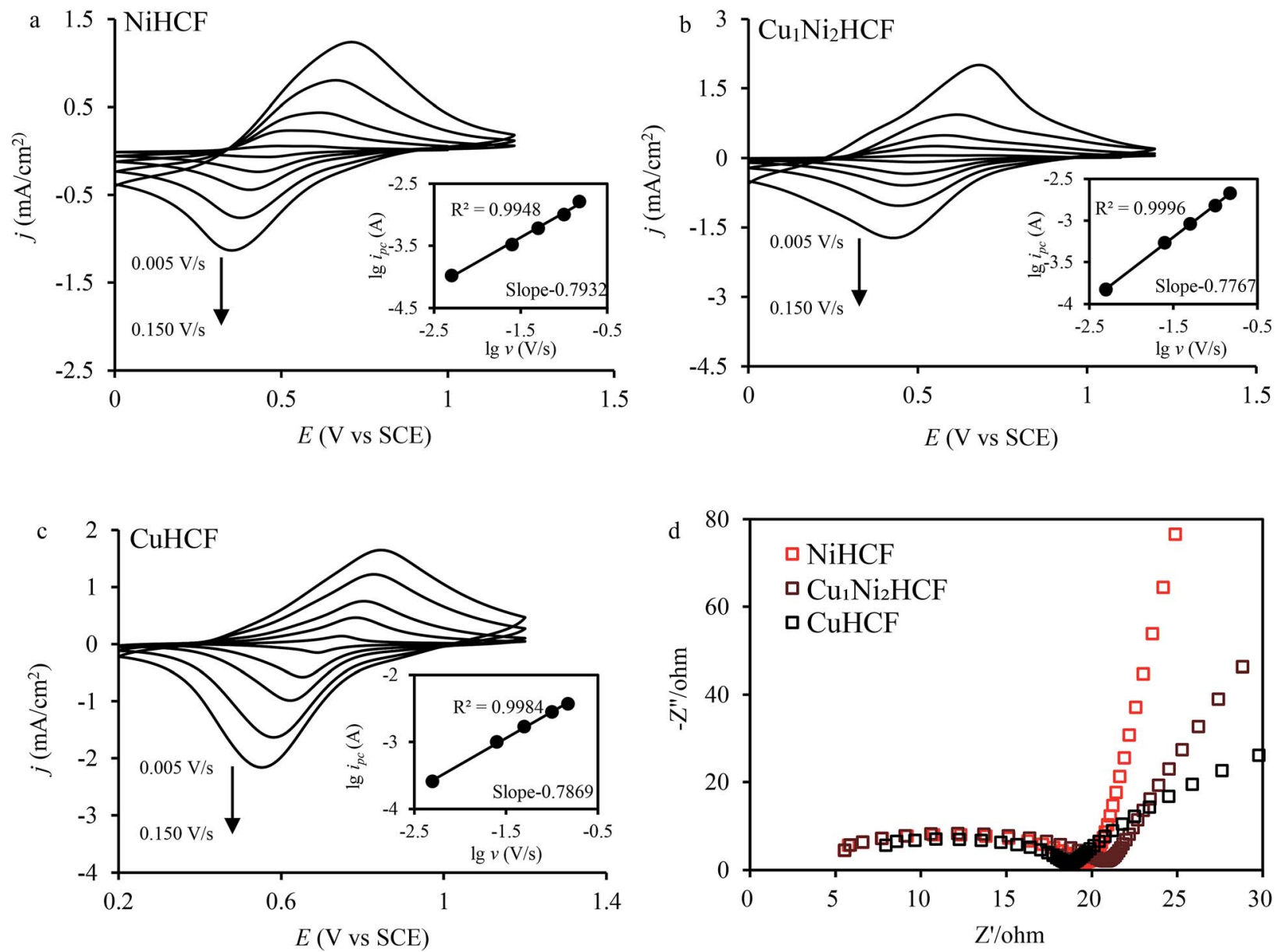

Fig. 7 (a, b and c) CV of $\mathrm{Cu}_{x} \mathrm{Ni}_{y} \mathrm{HCF}$ films in $0.5 \mathrm{M} \mathrm{Co}^{2+}$ solutions at different scan rates $\left(v=0.005,0.025,0.05,0.1,0.15 \mathrm{~V} \mathrm{~s}{ }^{-1}\right)$; insets show the logarithmic values of reduction peak current $\left(i_{\mathrm{pc}}\right)$ as a function of the logarithmic values of scan rate; (d) Nyquist plots of $\mathrm{Cu}_{x} \mathrm{Ni}_{y} \mathrm{HCF}$ films from $100 \mathrm{~Hz}$ to $1000 \mathrm{kHz}$

$\mathrm{Cu}_{1} \mathrm{Ni}_{2} \mathrm{HCF}$. The same conclusions can be drawn from NiHCF and CuHCF films (as shown in Fig. S1†).

3.2.3 Isotherm and kinetic studies. The effect of initial concentrations on the adsorption capacity of $\mathrm{Cu}_{1} \mathrm{Ni}_{2} \mathrm{HCF}$ films for $\mathrm{Co}^{2+}$ was studied and the results are shown in Fig. 9a. It has been found that the plot reflected a two-stage process, a steep ascent portion followed by a plateau extending to the equilibrium. The main reason is that the concentration gradient between the solution and the interface of the adsorbent increased with a rise in initial concentration, which enhanced the driving force for the diffusion of $\mathrm{Co}^{2+}$ from solution to the films. ${ }^{55,56}$

The Langmuir isotherm model and the Freundlich isotherm model were used to fit the experimental data. The Langmuir isotherm model assumes that only one monolayer of adsorbate molecule can be adsorbed on homogeneous sites of the adsorbent and the adsorbates do not react with each other. The Freundlich isotherm model is based on multilayer adsorption on a heterogeneous surface. The calculation results of the $Q_{\mathrm{e}}$, constants and correlation coefficient $\left(R^{2}\right)$ are listed in Table 2. The linear correlation coefficient $\left(R^{2}\right)$ from the Langmuir isotherm model is 0.9989 , which is higher than that calculated from the Freundlich isotherm model, and the value of $Q_{\mathrm{m}}$ from the Langmuir isotherm model is close to the practical $Q_{\mathrm{e}}$ obtained from experiment. It can be concluded that the Langmuir isotherm model can describe the adsorption process better than the Freundlich isotherm model, which is in agreement with the redox reaction. The results from the data in $1 \mathrm{mg} \mathrm{L}^{-1} \mathrm{Co}^{2+}$ solutions fitted to the intraparticle diffusion, pseudo-first-order and pseudo-second-order kinetic models are given in Table 2. The sorption process involves bulk diffusion, film diffusion and intraparticle diffusion (or pore diffusion). ${ }^{35}$ Fig. $8 \mathrm{~b}$ shows that two linear regions exist in the intraparticle diffusion plot. The adsorption system was stirred at a speed of $500 \mathrm{rpm}$. Thus, the two curves may indicate that the adsorption of $\mathrm{Co}^{2+}$ onto $\mathrm{Cu}_{1}$ $\mathrm{Ni}_{2} \mathrm{HCF}$ film occurred via two phases: ${ }^{57}$ film diffusion in the first linear part followed by intraparticle diffusion during the second linear portion. The linear portions of the two stages do not pass through the origin, and, $k_{\mathrm{p}, 1}$ is much greater than $k_{\mathrm{p}, 2}$, which suggests that both film and intraparticle diffusion processes are the probable rate-controlling steps. ${ }^{58}$ The constant $C_{1}$ increased with an increase in ion concentration, indicating the growth of the thickness of the boundary layer. The probability of external mass transfer was reduced, and the probability of internal mass transfer increased conversely. ${ }^{59}$ 

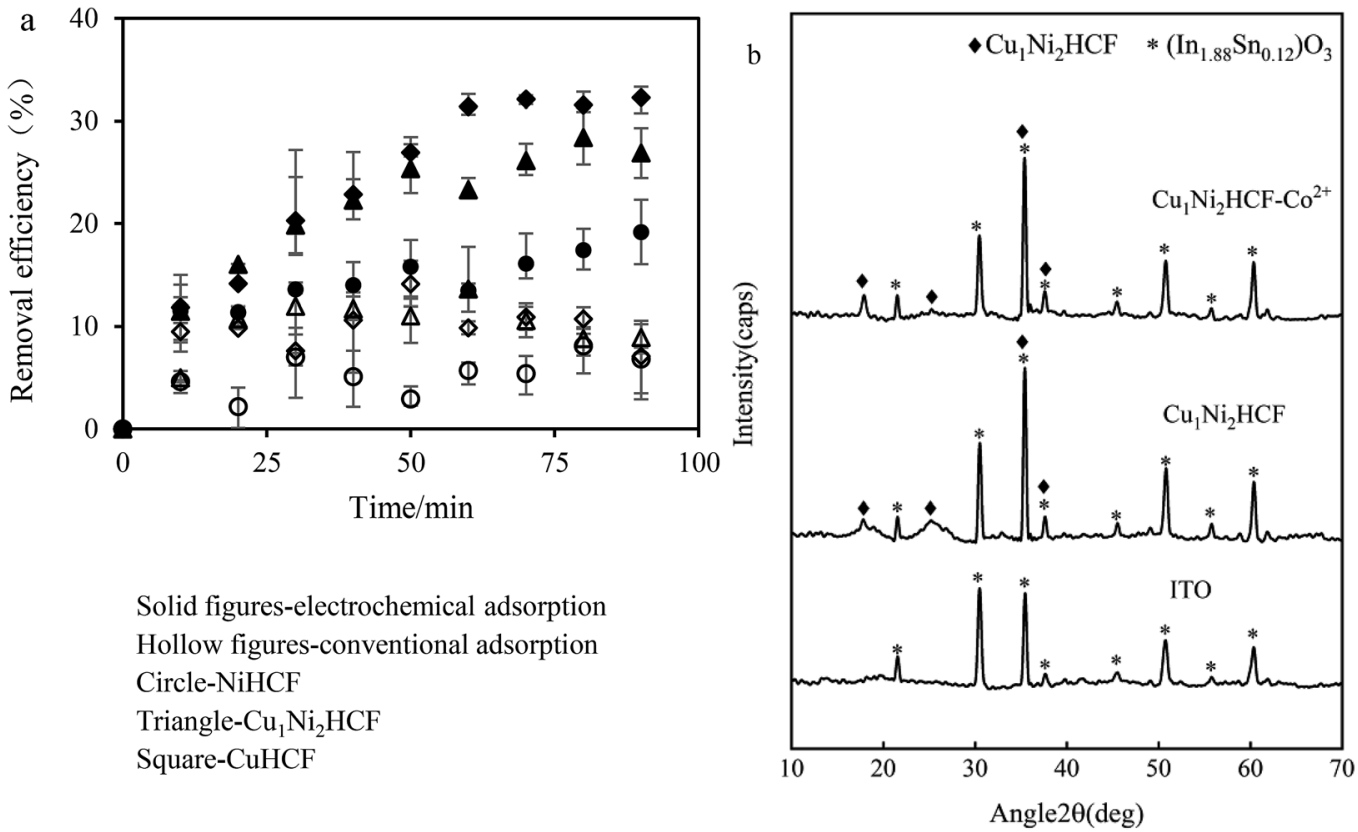

Solid figures-electrochemical adsorption Hollow figures-conventional adsorption Circle-NiHCF

Triangle- $\mathrm{Cu}_{1} \mathrm{Ni}_{2} \mathrm{HCF}$

Square-CuHCF

Angle2 $\theta(\mathrm{deg})$

$\mathrm{c}$
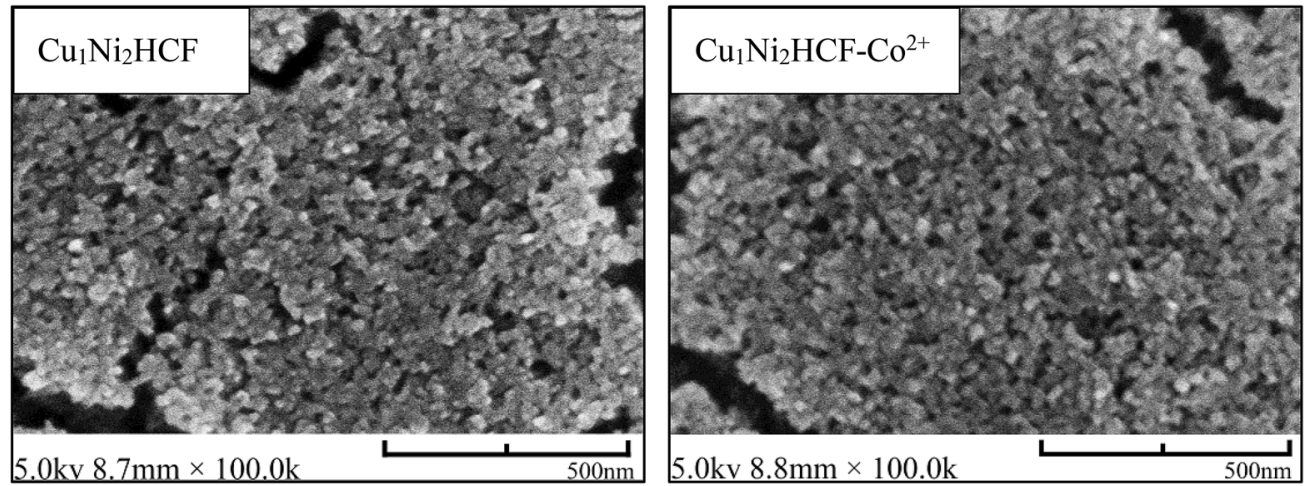

Fig. 8 (a) Removal efficiency of $\mathrm{Co}^{2+}$ onto $\mathrm{Cu}_{x} \mathrm{Ni}_{y} \mathrm{HCF}$ films vs. contact time $\left(\mathrm{Co}^{2+}\right.$ concentration: $1 \mathrm{mg} \mathrm{L}{ }^{-1}$, electrode area: $\left.15 \mathrm{~mm} \times 25 \mathrm{~mm}\right)$; (b) XRD patterns and (c) SEM images of $\mathrm{Cu}_{1} \mathrm{Ni}_{2} \mathrm{HCF}$ film before and after adsorption $\left(\mathrm{Cu}_{1} \mathrm{Ni}_{2} \mathrm{HCF}-\mathrm{Co}^{2+}\right)$.

Both the pseudo-first-order kinetic model and the pseudosecond-order kinetic model show a good fit to the experimental data with well-matching correlation coefficients at a low initial concentration. At a higher initial concentration, the correlation coefficient $\left(R^{2}\right)$ obtained from the pseudo-second-order kinetic model is higher than that of the pseudo-first-order kinetic model,
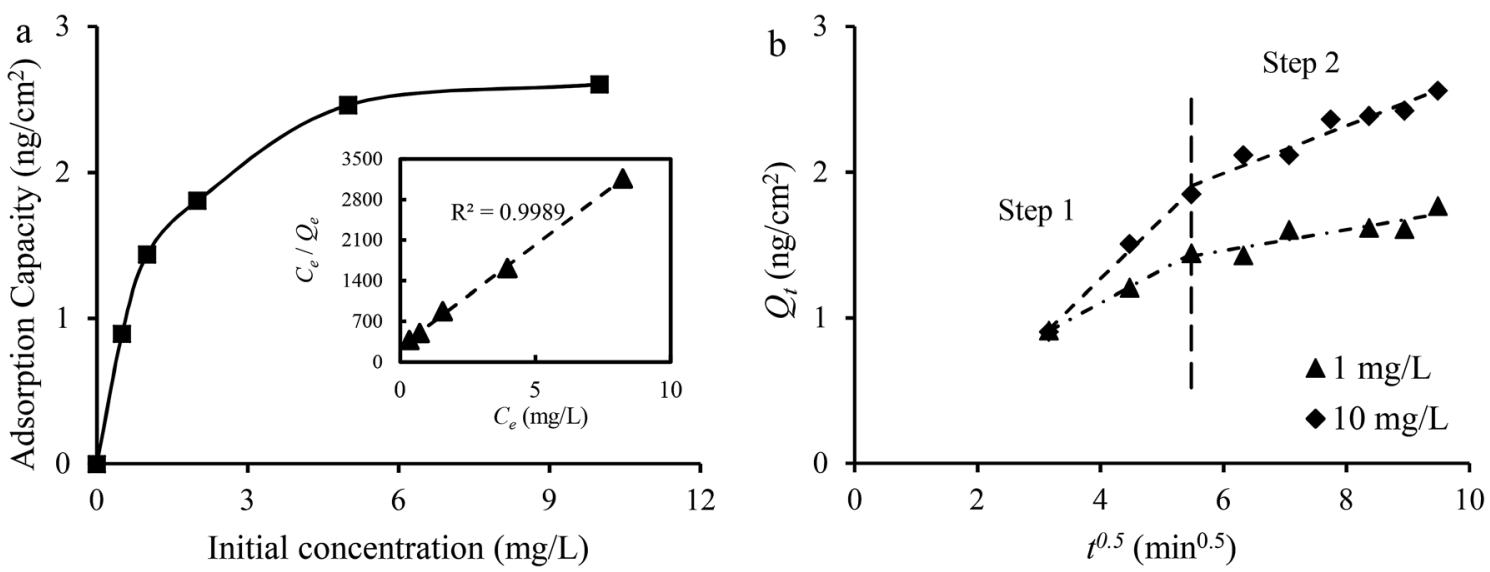

Fig. 9 (a) The effect of initial concentration on the adsorption capacity. The inset is the fitted result with the Langmuir isotherm model; (b) adsorption kinetic data in $1 \mathrm{mg} \mathrm{L}^{-1}$ and $101 \mathrm{mg} \mathrm{L}^{-1} \mathrm{Co}^{2+}$ solutions fitted with the intraparticle diffusion model. 
Table 2 The parameters and correlation coefficients of isotherm models and kinetic models

\begin{tabular}{|c|c|c|c|c|c|c|}
\hline \multirow[b]{2}{*}{ Isotherm models } & \multirow[b]{2}{*}{ Parameters } & & \multirow[b]{2}{*}{ Kinetic models } & \multirow[b]{2}{*}{ Constants } & \multicolumn{2}{|c|}{$\begin{array}{l}\text { Initial concentration } \\
\left(\mathrm{mg} \mathrm{L}^{-1}\right)\end{array}$} \\
\hline & & & & & 1 & 10 \\
\hline \multirow[t]{3}{*}{ Langmuir } & $Q_{\mathrm{m}}\left(\mathrm{mg} \mathrm{cm}^{-2}\right)$ & 0.0029 & Pseudo-first-order & $Q_{\mathrm{e}}\left(\mathrm{mg} \mathrm{cm}^{-2}\right)$ & 0.0017 & 0.0062 \\
\hline & $K_{\mathrm{L}}$ & 1.3263 & & $k_{1}$ & 0.0659 & 0.0044 \\
\hline & $R^{2}$ & 0.9989 & & $R^{2}$ & 0.9705 & 0.9083 \\
\hline & $R^{2}$ & 0.9370 & & $R^{2}$ & 0.9762 & 0.9730 \\
\hline & & & Intraparticle diffusion & $k_{\mathrm{p}, 1}$ & 0.0002 & 0.0004 \\
\hline & & & & $C_{1}$ & 0.0002 & -0.0004 \\
\hline & & & & $R^{2}$ & 0.9998 & 0.9932 \\
\hline & & & & $k_{\mathrm{p}, 2}$ & $7 \times 10^{-5}$ & 0.0002 \\
\hline & & & & $C_{2}$ & 0.0010 & 0.0010 \\
\hline
\end{tabular}

suggesting that the pseudo-second-order model is more suitable for describing the adsorption process. This may predict that electrochemical adsorption involved a complicated process, and chemical adsorption might be the rate-limiting step. ${ }^{60}$

\section{Conclusions}

In summary, the proportion of metals in $\mathrm{Cu}_{x} \mathrm{Ni}_{y} \mathrm{HCF}$ nanoparticle films can be controlled by the reactant ratio during the preparation process. With an increase in the $\mathrm{Cu}$ ratio, the crystallite size and $E_{\mathrm{f}}$ of $\mathrm{Cu}_{x} \mathrm{Ni}_{y} \mathrm{HCF}$ films varied from NiHCF films to CuHCF films. The results of SEM and XRD, together with the shape of the $\mathrm{CV}$ curves supported $\mathrm{Cu}^{2+}$ being inserted into the NiHCF lattice as countercations to maintain the electrical neutrality of the structure when the proportion of copper is less than 33\%; at higher molar fractions of $\mathrm{Cu}, \mathrm{Ni}$ was partially replaced by $\mathrm{Cu}$. $\mathrm{Cu}_{1} \mathrm{Ni}_{2} \mathrm{HCF}$ showed superior electrochemical properties of stability and current responses. The electrochemical adsorption behavior of $\mathrm{Co}^{2+}$ followed the Langmuir isotherm model and the pseudo-second order model. Our study reveals the potential of $\mathrm{Cu}_{x} \mathrm{Ni}_{y} \mathrm{HCF}$ nanoparticle films as a promising technology for the recovery of $\mathrm{Co}^{2+}$ from spent LIBs.

\section{Conflicts of interest}

There are no conflicts to declare.

\section{Acknowledgements}

Authors acknowledge the research staffs in University of Chinese Academy of Sciences to provide technical assistance on FE-SEM, XRD and FTIR test and analysis. This work was supported by National Natural Science Foundation of China (Contract No. 21806166), Beijing Natural Science Foundation (No. 2184128), and Key Program of Chinese Academy of Sciences (No. KFZD-SW315).

\section{References}

1 X. Yao, R. Zhao, L. Chen, J. Du, C. Tao, F. Yang and L. Dong, Appl. Catal., B, 2017, 208, 82-93.

2 A. Paolella, C. Faure, V. Timoshevskii, S. Marras, G. Bertoni, A. Guerfi, A. Vijh, M. Armand and K. Zaghib, J. Mater. Chem. A, 2017, 5, 18919-18932.

3 S. Zhang, P. Kang, S. Ubnoske, M. K. Brennaman, N. Song, R. L. House, J. T. Glass and T. J. Meyer, J. Am. Chem. Soc., 2014, 136, 7845-7848.

4 F. Yu, F. Li, B. Zhang, H. Li and L. Sun, ACS Catal., 2015, 5, 627-630.

5 A. Farhangfar, IEEE Sens. J., 2018, 18, 925-932.

6 M. L. M. Firmino, S. Morais, A. N. Correia, P. de Lima-Neto, F. A. O. Carvalho, S. S. L. Castro and T. M. B. F. Oliveira, Chem. Eng. J., 2017, 323, 47-55.

7 X. Zhang, J. Jiang, Y. Chen, K. Cheng, F. Yang, J. Yan, K. Zhu, K. Ye, G. Wang, L. Zhou and D. Cao, Chem. Eng. J., 2018, 335, 321-329.

8 X. Bie, K. Kubota, T. Hosaka, K. Chihara and S. Komaba, J. Power Sources, 2018, 378, 322-330.

9 U. Shanker, V. Jassal and M. Rani, J. Environ. Chem. Eng., 2017, 5, 4108-4120.

10 L. Z. Cai, Q. S. Chen, C. J. Zhang, P. X. Li, M. S. Wang and G. C. Guo, J. Am. Chem. Soc., 2015, 137, 10882-10885.

11 V. Svitkova, J. Blaskovicova, M. Tekelova, B. M. Kallai, T. Ignat, V. Horackova, P. Skladal, P. Kopel, V. Adam, D. Farkasova and J. Labuda, Sens. Actuators, B, 2017, 243, 435-444.

12 M. Baghayeri, R. Ansari, M. Nodehi, I. Razavipanah and H. Veisi, Microchim. Acta, 2018, 185.

13 R. Z. Chen, H. Tanaka, T. Kawamoto, M. Asai, C. Fukushima, M. Watanabe, M. Kurihara, M. Arisaka and T. Nankawa, Procedia Eng., 2012, 44, 1728-1730.

14 Z. Jia, X. Cheng, Y. Guo and L. Tu, Chem. Eng. J., 2017, 325, 513-520.

15 I. Zunke, D. Kloss, A. Heft, J. Schmidt and B. Gruenler, Surf. Coat. Technol., 2016, 289, 186-193. 
16 P. Hosseini, G. Wittstock and I. Brand, J. Electroanal. Chem., 2018, 812, 199-206.

17 W.-R. Cai, G.-Y. Zhang, T. Song, X.-J. Zhang and D. Shan, Electrochim. Acta, 2016, 198, 32-39.

18 A. Senthil Kumar, P. Barathi and K. Chandrasekara Pillai, J. Electroanal. Chem., 2011, 654, 85-95.

19 K. M. Rachna, M. Rani and U. Shanker, Chem. Eng. J., 2018, 348, 754-764.

20 A. V. N. Kumar and J. Joseph, J. Phys. Chem. C, 2015, 119, 296-304.

21 P. Xu, G. Wang, H. Wang, Y. Li, C. Miao, J. Qu, Y. Zhang, F. Ren, K. Cheng, K. Ye, K. Zhu, D. Cao and X. Zhang, Chem. Eng. J., 2017, 328, 834-843.

22 S. Ghasemi, R. Ojani and S. Ausi, Int. J. Hydrogen Energy, 2014, 39, 14918-14926.

23 W. F. Li, F. Zhang, X. D. Xiang and X. C. Zhang, ChemElectroChem, 2018, 5, 350-354.

24 P. C. Pandey and A. K. Pandey, Analyst, 2013, 138, 2295-2301.

25 J. Wang, R. Chen, X. Long and Z. Li, J. Electroanal. Chem., 2018, 810, 191-198.

26 M.-S. Wu, L.-J. Lyu and J.-H. Syu, J. Power Sources, 2015, 297, 75-82.

27 P. J. Kulesza, M. A. Malik, R. Schmidt, A. Smolinska, K. Miecznikowski, S. Zamponi, A. Czerwinski, M. Berrettoni and R. Marassi, J. Electroanal. Chem., 2000, 487, 57-65.

28 S. Zamponi, M. Berrettoni, P. J. Kulesza, K. Miecznikowski, M. A. Malik, O. Makowski and R. Marassi, Electrochim. Acta, 2003, 48, 4261-4269.

29 W. Li, F. Zhang, X. Xiang and X. Zhang, ChemElectroChem, 2017, 4, 2870-2876.

30 M. Giorgetti, L. Guadagnini, D. Tonelli, M. Minicucci and G. Aquilanti, Phys. Chem. Chem. Phys., 2012, 14, 5527-5537.

31 R. Chen, H. Tanaka, T. Kawamoto, M. Asai, C. Fukushima, M. Kurihara, M. Watanabe, M. Arisaka and T. Nankawa, Electrochem. Commun., 2012, 25, 23-25.

32 A. Abbaspour and M. A. Kamyabi, J. Electroanal. Chem., 2005, 576, 73-83.

33 X. Cui, L. Hong and X. Lin, J. Electroanal. Chem., 2002, 526, 115-124.

34 L. Guadagnini, M. Giorgetti, F. Tarterini and D. Tonelli, Electroanalysis, 2010, 22, 1695-1701.

35 R. Chen, H. Tanaka, T. Kawamoto, M. Asai, C. Fukushima, H. Na, M. Kurihara, M. Watanabe, M. Arisaka and T. Nankawa, Electrochim. Acta, 2013, 87, 119-125.

36 S. Q. Chang, L. Chang, W. Han, Z. Li, Y. D. Dai and H. Q. Zhang, J. Radioanal. Nucl. Chem., 2018, 316, 209-219.

37 J. Y. Liao, Q. Hu, B. K. Zou, J. X. Xiang and C. H. Chen, Electrochim. Acta, 2016, 220, 114-121.
38 S. J. Gerber and E. Erasmus, Mater. Chem. Phys., 2018, 203, 73-81.

39 Y. Zong, Y. Zhang, X. Lin, D. Ye, X. Luo and J. Wang, J. Radioanal. Nucl. Chem., 2017, 311, 1577-1591.

40 S. Manakasettharn, A. Takahashi, T. Kawamoto, K. Noda, Y. Sugiyama and T. Nakamura, Anal. Chem., 2018, 90, 4856-4862.

41 S.-C. Jang, S.-M. Kang, Y. Haldorai, K. Giribabu, G.-W. Lee, Y.-C. Lee, M. S. Hyun, Y.-K. Han, C. Roh and Y. S. Huh, Sci. Rep., 2016, 6, 7845-7848.

42 S. Naeimi and H. Faghihian, Sep. Purif. Technol., 2017, 175, 255-265.

43 C. W. Ng, J. Ding, Y. Shi and L. M. Gan, J. Phys. Chem. Solids, 2001, 62, 767-775.

44 M. Hu, S. Furukawa, R. Ohtani, H. Sukegawa, Y. Nemoto, J. Reboul, S. Kitagawa and Y. Yamauchi, Angew. Chem., Int. Ed., 2012, 51, 984-988.

45 G. Kalaiyarasan, K. Aswathi and J. Joseph, Int. J. Hydrogen Energy, 2017, 42, 22866-22876.

46 M. Ciabocco, M. Berrettoni, S. Zamponi, R. Spinosi and P. Conti, Int. J. Electrochem. Sci., 2018, 13, 5535-5551.

47 J. X. Wang, R. Z. Chen, X. X. Long and Z. J. Li, J. Electroanal. Chem., 2018, 810, 191-198.

48 J. Kukulka-Walkiewicz, J. Stroka, M. A. Malik, P. J. Kulesza and Z. Galus, Electrochim. Acta, 2001, 46, 4057-4063.

49 J. C. Kemmegne-Mbouguen, L. Angnes, E. Mouafo-Tchinda and E. Ngameni, Electroanalysis, 2015, 27, 2387-2398.

50 F. Jalali and S. Ranjbar, Russ. J. Electrochem., 2014, 50, 482489.

51 Y. Zhang, Y. Liu, Z. Chu, L. Shi and W. Jin, Sens. Actuators, B, 2013, 176, 978-984.

52 Y. Wang, Y. Yang, X. Zhang, C. Liu and X. Hao, J. Solid State Electrochem., 2015, 19, 3157-3168.

53 H.-C. Zhao, P. Zhang, S.-H. Li and H.-X. Luo, Chin. J. Anal. Chem., 2017, 45, 830-836.

54 T. Vincent, C. Vincent and E. Guibal, Molecules, 2015, 20, 20582-20613.

55 Y. Zhu, W. Wang, H. Zhang, X. Ye, Z. Wub and A. Wang, Chem. Eng. J., 2017, 327, 982-991.

56 Y. Wan, X. Liu, P. Liu, L. Zhao and W. Zou, Sci. Total Environ., 2018, 639, 428-437.

57 J. Q. Deng, X. D. Li, Y. G. Liu, G. M. Zeng, J. Liang, B. Song and X. Wei, Ecotoxicol. Environ. Saf., 2018, 165, 211-218.

58 L. Lv, N. Chen, C. Feng, J. Zhang and M. Li, RSC Adv., 2017, 7, 27992-28000.

59 C. Theivarasu and S. Mylsamy, Int. J. Eng. Sci. Technol., 2010, 2, 6284-6292.

60 S. M. El-Bahy, D. A. Fadel, Z. M. El-Bahy and A. M. Metwally, J. Environ. Chem. Eng., 2018, 6, 1875-1885. 